\title{
The species of Trichophthalma (Diptera: Nemestrinidae) of Argentina
}

\author{
Diego MEDAN ${ }^{1} \&$ Mariano DEVOTO ${ }^{2}$
}

\begin{abstract}
Cátedra de Botánica, Facultad de Agronomía de la Universidad de Buenos Aires. Av. San Martín 4453, 1417 Buenos Aires, Argentina. ${ }^{1}$ diemedan@agro.uba.ar ${ }^{2}$ Current address: School of Biological Sciences, University of Bristol, Woodland Road, Bristol BS8 1UG, Reino Unido
\end{abstract}

\begin{abstract}
The genus Trichophthalma (Diptera: Nemestrinidae) was last revised for Argentina in 1939. Since then several species were newly cited or described for this country but no comprehensive treatment of the genus was published. The analysis of our own extensive collections and of the holdings of Trichophthalma at three major entomological collections in Argentina showed that eleven different species of Trichophthalma exist in this country, and that three of these have an unexpectedly ample distribution, including areas unconnected to the southern temperate forests of Patagonia, where all previous records were concentrated. A key for all Argentinean species is provided.
\end{abstract}

Key words: tanglewing flies - geographical distribution.

Resumen: El género Trichophthalma (Diptera: Nemestrinidae) fue revisado para la Argentina por última vez en 1939. Desde entonces se citaron y describieron varias especies nuevas para ese país sin que se haya publicado un tratamiento completo del género. Sobre la base de material de los autores, y del conservado en las tres mayores colecciones entomológicas de Argentina se concluye que existen once especies de Trichophthalma en el país, de las cuales tres poseen una distribución geográfica inesperadamente amplia, que incluye regiones desconectadas de los bosques templados de Patagonia, en los cuales se concentraban todos los registros previos del género. Se presenta una clave para todas las especies argentinas.

Palabras clave: nemestrínidos - distribución geográfica.

\section{INTRODUCTION}

The flies of the family Nemestrinidae (Diptera, Brachycera, Asiloidea), commonly known as tanglewing flies, are rather primitive among Diptera (Willemstein, 1987; Mostovski \& Martinez Delclos, 2000). The number of described species, which was 150 nearly forty years ago (Cole, 1969), has grown with the addition of new species (e.g., Bernardi, 1975; 1977) while still many might remain undescribed (Goldblatt \& Manning, 2000; $\mathrm{N}$. Woodley personal communication).

Nemestrinidae are widespread throughout the globe, but they show a higher concentration in some areas: from the Mediterranean to Turkistan, eastern Australia, southern Africa, Chile and Argentina (Bernardi, 1973). Two extant subfamilies, the Nemestrininae and the Hirmoneurinae, are the most widely distributed. Nemestrininae genera are geographically segregated in South America and Australia (genus Trichophthalma), southern Africa (Prosoeca and Stenobasipteron) and the Palearctic region (Nemestrinus and Stenopteromyia, with a branch that, later, reached Africa, giving rise to Moegistorhynchus) (Bernardi, 1973).
Trichophthalma is the only genus of Nemestrinidae that occurs both in Australia ( 45 species) and South America (21 species) (Bernardi, 1973; 1975). This disjunct distribution resembles that of many other taxa with an ancient Gondwanian origin (Raven \& Axelrod, 1974; 1975 and references therein). In spite of its primitiveness, Trichoph-thalma shows a rather specialized character (shared by all Nemestrininae): the proboscis is always well developed, thus enabling these flies to reach nectar hidden in deep flower tubes. This has lead to reports of flower visitation by tanglewing flies in South America (Edwards, 1930; Devoto et al., 2006) and South Africa (Marloth, 1908; Goldblatt \& Manning, 2000), some of which are remarkable examples of specialized pollination mutualisms (e.g. Manning \& Goldblatt, 1995). However, whereas southern African species have received much attention (Johnson \& Steiner, 2000; Goldblatt \& Manning, 2000 and references therein), the ecology and actual distribution of most southern South American species remain widely unknown (Peña, 1996; but see Devoto \& Medan, 2006).

The number of Trichophthalma species known for Argentina increased steadily during the past century. On the basis of material collected in the 
province of Chubut, Lichtwardt (1910) described two species (originally placed in the genus Eurygastromyia), T. murina (Lichtwardt) and a second one that resulted a junior synonym of $T$. amoena Bigot (nomenclature follows Bernardi, 1973). Edwards (1930) recorded in the province of Río Negro two taxa previously described for Chile, T. philippii Rondani and T. niveibarbis (Bigot) (sub T. glauciventris Edwards), and added a Río Negro record for T. amoena. Stuardo Ortiz (1939) recorded another Chilean species, $T$. jaffueli Stuardo Ortiz for Santa Cruz, and reported a possible new taxon (Trichophthalma sp., i.e., a formal epithet was not provided) on the basis of three females, one labelled 'Santa Cruz, Patagonia (nr. 7411)' apparently collected by C. Ameghino, another labelled 'San Jorge, Patagonia (nr. 39371)' (unknown collector), and a third labelled 'Trichophthalma Morenii n. sp.' without collector nor locality, but which Stuardo Ortiz (1939) assumed to have been collected by the naturalist Francisco P. Moreno somewhere in the Argentinean Patagonia. In his revision of the Chilean Nemestrinidae Angulo (1971) provided a record for Chubut of his newly described T. tigrina Angulo. In his synopsis of Nemestrinidae Bernardi (1973) recorded for Argentina two other Chilean taxa, T. nubipennis Rondani for the Neuquén province and T. sexmaculata Edwards for Río Negro. He also applied the name T. morenii Stuardo Ortiz to the unnamed species of Stuardo Ortiz (1939), which resulted in a nomen nudum. Later Bernardi (1975) described a new species, T. anguloi Bernardi, on the basis of a male specimen from Argentina (collector and specific locality unknown).

In recent years, studies on the pollination ecology of the Nothofagus southern temperate forests of Argentina led to two further Chilean species being recorded in Neuquén, T. andina (Philippi) and T. porteri Stuardo Ortiz (Devoto \& Medan, 2006), and to the extension of the known distributions of several other taxa: T. amoena in Neuquén, T. jaffueli in Río Negro and Neuquén (Vázquez, 2002) and T. philippii and T. niveibarbis in Neuquén (Devoto \& Medan, 2006). Devoto \& Medan (2006) also reported two Trichophthalma morphospecies from Neuquén that could not be unequivocally assigned to any of the known species of the genus. These taxa were provisionally referred to as $T$. sp. 1 and $T$. sp. 2 by these authors.

Thus, by 2006 fourteen Trichophthalma nominal species and morphospecies had been recorded for Argentina, of which "T. morenii", T. anguloi, $T$. sp. 1 and $T$. sp. 2 were apparently exclusive of this country, while the other ten species were also known for Chile. In an attempt to clarify this panorama, we contrasted the published specific descriptions of Trichophthalma with our own collections from Patagonia and with the holdings of this genus kept at three major entomological collections of Argentina.

\section{MATERIAL AND METHODS}

Published descriptions (Stuardo Ortiz, 1939; Angulo, 1971; Bernardi, 1975) were compared with the material of Trichophthalma deposited in our own collection at the Facultad de Agronomía, Universidad de Buenos Aires (hereafter: FAUBA) (>50 specimens), and in the entomological collections of the Museo de La Plata (La Plata), the Instituto Miguel Lillo (Tucumán) (hereafter: LILLO), and the Museo Argentino de Ciencias Naturales 'Bernardino Rivadavia' (Buenos Aires) (together, ca. 110 specimens). Additionally we examined photographs of the holotype and the allotype of T. tigrina, deposited in the entomological collection of the Universidad de Concepción, Chile. The metasomal terga $(\mathrm{T})$ are identified with Arabic numerals.

\section{RESULTS AND DISCUSSION}

\section{The distribution of Trichophthalma in Argentina}

Nine of the species of Trichophthalma previously recorded for Argentina were found among the examined material (Table 1, Figs. 1-9). No material was seen of the enigmatic T. anguloi (which is still known from the type specimen only) and of T. sexmaculata. Except for T. porteri, found only in Neuquén, all other species were recorded for two or more provinces, with a maximum of five provinces in the case of $T$. jaffueli. The newly reported records extend the area of five of the species: T. andina, T. jaffueli, T. murina, T. nubipennis and T. tigrina.

An unexpected result was the finding of Trichophthalma in areas of Argentina biogeographically unrelated to the southern temperate forests dominated by the Southern Beeches (Nothofagus spp.), the region in which all previous records of Trichophthalma were concentrated. Although the analysis of the zoogeographical implications of this extended distribution of Trichophthalma is out of the scope of this paper, the presence of three Trichophthalma species (T. jaffueli, T. murina and T. nubipennis) in one or two of the provinces Catamarca, Córdoba, Misiones, and Santiago del Estero (Table 1), indi- 


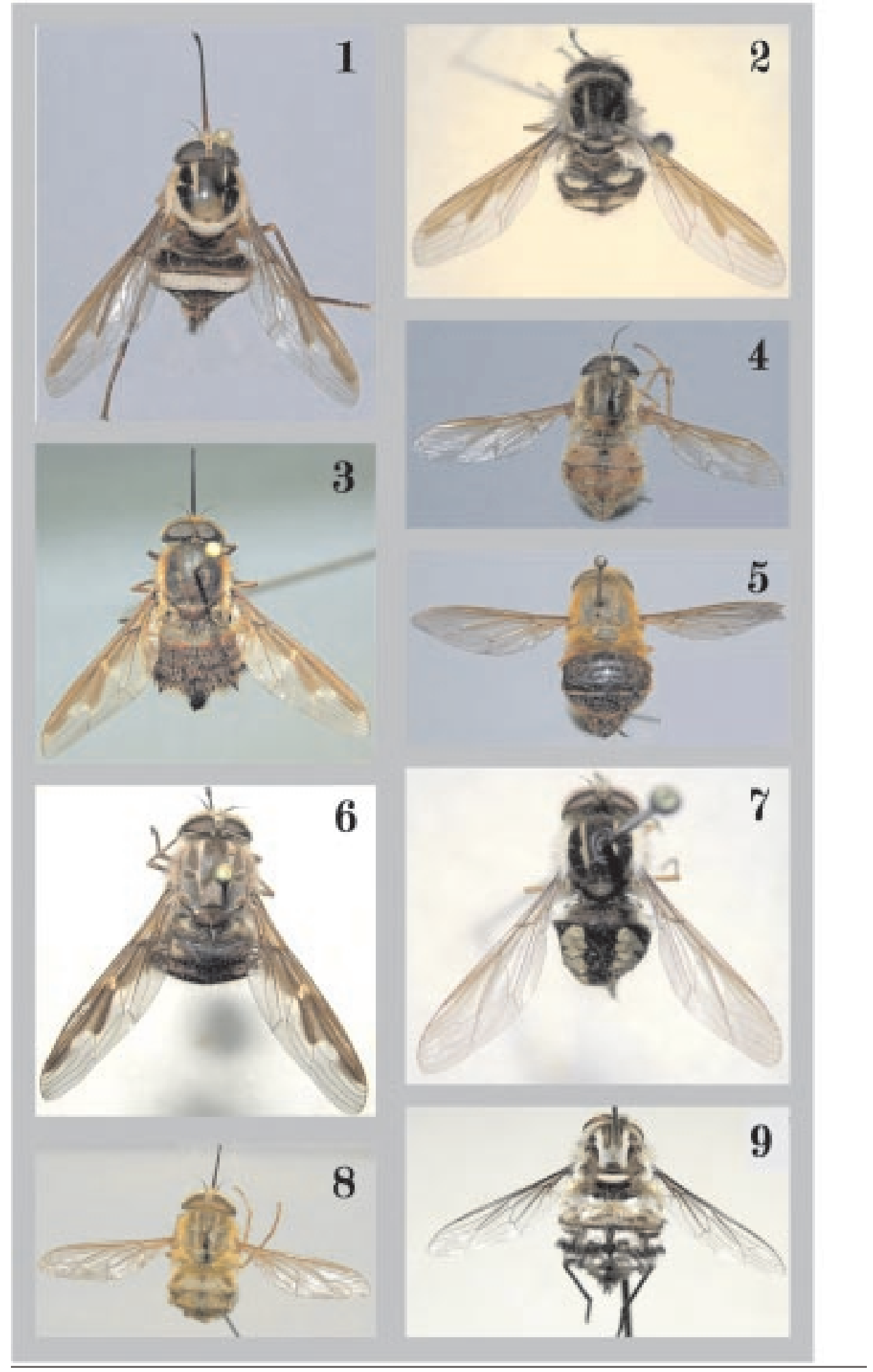

Figs. 1-9. Habitus of Trichophthalma spp. of Argentina. 1, T. philippi; 2, T. amoena; 3, T. niveibarbis; 4, T. nubipennis; 5, T. andina; 6, T. porteri; 7, T. jaffueli; 8, T. murina; 9, T. tigrina. No material of T. anguloi and T. sexmaculata was available to authors. 
Table 1. Geographical distribution of accepted Trichophthalma spp. in Argentina. Provinces in bold type are disconnected from the southern temperate forests. Small type and capital letters indicate already published and new records, respectively. Letters in parentheses indicate unconfirmed published records. The distribution of T. anguloi is unknown.

\begin{tabular}{|c|c|c|c|c|c|c|c|c|}
\hline \multirow[b]{2}{*}{ species } & \multicolumn{8}{|c|}{ Provinces } \\
\hline & 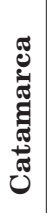 & 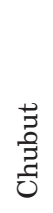 & 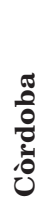 & 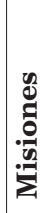 & 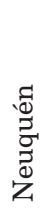 & 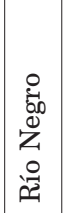 & 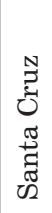 & 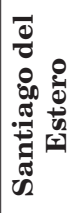 \\
\hline $\begin{array}{l}\text { amoena } \\
\text { andina } \\
\text { jaffueli } \\
\text { murina } \\
\text { niveibarbis } \\
\text { nubipennis } \\
\text { sexmaculata } \\
\text { tigrina } \\
\text { philippii } \\
\text { porteri }\end{array}$ & $\mathrm{X}$ & $(\mathrm{x})$ & $\mathrm{X}$ & $\mathrm{X}$ & $\begin{array}{l}x \\
x \\
x \\
X \\
x \\
x \\
X \\
x \\
x\end{array}$ & $\begin{array}{l}(\mathrm{x}) \\
\mathrm{x} \\
(\mathrm{x}) \\
(\mathrm{x}) \\
(\mathrm{x})\end{array}$ & $\begin{array}{l}\mathrm{X} \\
\mathrm{x} \\
\mathrm{X}\end{array}$ & $\mathrm{X}$ \\
\hline
\end{tabular}

cates that this genus is by no means restricted to the Nothofagus forests adjacent to Chile, as previously thought. Perhaps it is no coincidence that the species with the widest distribution ( $T$. jaffueli) showed also the highest ecological amplitude among its congenerics in north-western Patagonia (Devoto \& Medan 2006).

\section{Trichophthalma tigrina Angulo}

When examining the material of Trichophthalma deposited in the Museo Argentino de Ciencias Naturales 'Bernardino Rivadavia' we found the three females used by Stuardo Ortiz (1939) to describe the species that he recognized as new, but he left unnamed (see Introduction), i.e., the one which later Bernardi (1973) referred to as $T$. morenii. The labels accompanying these specimens exactly correspond to Stuardo Ortiz (1939) specifications, except that the specimen labeled Trichophthalma Morenii n. sp.' carries also a label with the number 39373. Interestingly, these specimens exactly matched the Neuquén female specimen we had called Trichophthalma sp. 1 (Devoto \& Medan, 2006). Moreover, all this material seemed to correspond with the description of T. tigrina (Angulo, 1971), a view which was confirmed by the identification of photographs of our Neuquén material as T. tigrina by Andrés Angulo (pers. comm. 2006). Also, the photographs of the typical material of $T$. tigrina provided to us by Dr. Angulo leave no doubt about the coincidence of T. morenii, our morphospecies T. sp. 1 and T. tigrina. Perhaps all this would have been detected earlier had Angulo (1971) examined more material of Trichophthalma from Argentina when he revised the genus for Chile, or had Bernardi (1973) examined material of T. morenii and $T$. tigrina when he revised the world genera of Nemestrinidae. Because Bernardi's (1973) main objective was to better define taxa at the generic level, he studied material from many, but not all species recognized in his paper: he studied no material of T. tigrina or T. Morenii. The name $T$. morenii was arbitrarily attributed to Stuardo Ortiz by Bernardi (1973), and was never made available, so it should be considered a nomen nudum.

\section{Trichophthalma amoena Bigot}

The examination of additional specimens of T. amoena Bigot suggested us that the specimen we called T. sp. 2 in a previous study (Devoto \& Medan, 2006) fell within the phenotypical range of that species. This view was confirmed by the identification of photographs of our Neuquén material as T. amoena by Andrés Angulo (pers. comm. 2006).

\section{New records of Trichophthalma for Ar- gentina}

Trichophthalma andina (Philippi). 1 female, province Santa Cruz: El Chaltén, visiting Hypochaeris radicata L., col. D. Medan, 31.01.2005 (FAUBA).

Trichophthalma jaffueli Stuardo Ortiz. 2 females: province Misiones: Apóstoles, col. Willink, Fidalgo, Claps \& Domínguez, 19.11.1980 (LILLO); province Santiago del Estero: San Ramón, col. M. L. Aczél, 09.04.1949 (LILLO).

Trichophthalma murina (Lichtwardt). 3 females: province Córdoba: Departamento San Martín, col. F. López, 27.01.1948 (LILLO); province Neuquén: Chapelco, $1700 \mathrm{~m}$ a.s.l., col. L. Schajovskoi, 24.11.1952 (LILLO); province Santa Cruz: El Chaltén, visiting Hypochaeris radicata L., col. Diego Medan, 03.02.2005 (FAUBA).

Trichophthalma nubipennis Rondani. 1 female: province Catamarca: Hualfín, col. A. Ares, 18.11.1948 (LILLO); 1 male and 1 female, province Córdoba, col. Padre López, 19.11.1949 (LILLO).

Trichophthalma tigrina Angulo. 1 female, province Neuquén: costa Lago Huechulafquen, visiting Adesmia boronioides J.D. Hooker, col. D. 
Medan, M. Devoto \& J. P. Torretta, 13.12.2003 (FAUBA).

\section{Key to the species of Trichophthalma of Argentina}

1. Wings with anterior half mainly dark brown, posterior half clear, these areas separated by an irregular line

-. Wings clear or only gradually darkened towards costa

2. T3 or T4 pale or with a pale fascia .............. 3

-. T3 and T4 not pale nor conspicuously fasciated

... 4

3. T3 blackish, T4 pale fasciated posteriorly, scutellum pale T. philippii

-. T3 white, T4 black, scutellum black T. amoena

4. Mesonotum mainly blackish with two conspicuous pale longitudinal stripes 5

-. Mesonotum light grey or brown with two thin pale longitudinal stripes ... ... 6

5. Abdomen largely dark, but with posterior margins of T3-5 continuously grey

T. niveibarbis

-. Abdomen blackish with six pale spots, the first pair located at the base of T3

T. sexmaculata

6. Proboscis 2.5 times head height

...T. nubipennis

-. Proboscis 4 times head height ........ T. porteri

7. Proboscis shorter than head height... T. anguloi

-. Proboscis longer than head height 8

8. Body entirely covered by reddish brown indument T. andina

-. Indument variable but not entirely reddish . brown ... 9

9. T3-5 gray, anteriorly with three separate to confluent dark brown spots T. murina

-. T3-5 without anterior, confluent dark spots 10

10. Body indumentum sparse, light brown to yel low T. jaffueli

-. Body indumentum dense, woolly, white interspersed with black T. tigrina

\section{ACKNOWLEDGMENTS}

The help of the curators of the consulted collections (Alberto H. Abrahamovich, Guillermo Claps and Arturo Roig-Alsina) is gratefully acknowledged. We also thank Dr. Andrés Angulo for sending us photographs of the holotype and the allotype of T. tigrina, and Guillermo Claps and an anonymous reviewer for useful comments on previous drafts of this paper.

\section{BIBLIOGRAPHY}

Angulo, A. 1971. Los Nemestrínidos de Chile (Diptera: Nemestrinidae). Gayana Zoología 19: 1-172.

Bernardi, N. 1973. The genera of the family Nemestrinidae (Diptera: Brachycera). Arquivos de Zoologia 24: 211-318.

- 1975. Uma nova Trichophthalma da Argentina (Diptera, Nemestrinidae). Revista Brasileira de Entomologia 19: 123-125.

- 1977. The tribe of Hyrmophlaebini (Diptera Nemestrinidae Hirmoneurinae) with 13 new species from South America. Papeis Avulsos de Zoologia 30: 239-259.

Cole, F.R. 1969. The flies of western North America. University of California Press, Berkeley, California, USA, $693 \mathrm{p}$.

Devoto, M. \& D. Medan. 2006. Diversity, distribution and floral specificity of tangle-veined flies (Diptera: Nemestrinidae) in northwest Patagonia, Argentina. Revista Chilena de Historia Natural 79: 29-40.

Devoto, M., Montaldo, N.H. \& D. Medan. 2006. Mixed hummingbird-long-proboscid-fly pollination in 'ornithophilous' Embothrium coccineum (Proteaceae) along a rainfall gradient in Patagonia, Argentina. Austral Ecology 31: 512-519.

Edwards, F. W. 1930. Nemestrinidae. In: Diptera of Patagonia and south Chile, Volume 2: 179-187. British Museum of Natural History, London, United Kingdom.

Goldblatt, P. \& J.C. Manning. 2000. The long proboscid fly pollination system in southern Africa. Annals of the Missouri Botanical Garden 87: 146-170.

Johnson, S.D. \& K.E. Steiner. 2000. Generalization versus specialization in plant pollination systems. Trends in Ecology and Evolution 15: 140-143.

Lichtwardt, B. 1910. Beitrag zur Kentniss der Nemestriniden (Dipt.). Teil V. Über amerikanische Arten. Deutsch. Ent. Zeitschr. 1910: 589-624.

Manning J.C. \& P. Goldblatt. 1995. The Prosoeca peringueyi (Diptera: Nemestrinidae) pollination guild in southern Africa: long-tongued flies and their tubular flowers. Annals of the Missouri Botanical Garden 82: 517-534

Marloth, R. 1908. Some observations on entomophilous flowers. South African Association for the Advancement of Science 4: 110-113.

Mostovski, M.B. \& X. Martínez Delclos. 2000. New Nemestrinoidea (Diptera: Brachycera) from the Upper Jurassic-Lower Cretaceous of Eurasia, taxonomy and palaeobiology. Entomological Problems 31: 137-148.

Peña, G.L.E. 1996. Introducción al estudio de los insectos de Chile. Editorial Universitaria, Santiago, Chile, $253 \mathrm{p}$.

Raven, P.H. \& D.I. Axelrod. 1974. Angiosperm bioge- 
ography and past continental movements. Annals of the Missouri Botanical Garden 61: 539-673.

- 1975. History of the flora and fauna of Latin America. American Science 63: 420-429.

Stuardo Ortiz, C. 1939. Los Nemestrinidae (Diptera) de la República Argentina. Physis 17: 77-94.

Vázquez, D. P. 2002. Interactions among introduced un- gulates, plants, and pollinators: a field study in the temperate forest of the Southern Andes. Ph.D. Dissertation. Department of Ecology and Evolutionary Biology, University of Tennessee, Knoxville.

Willemstein, S. C. 1987. An evolutionary basis for pollination ecology. Leiden University Press, Leiden, The Netherlands, $425 \mathrm{p}$.

Recibido: 15-I-2008 Aceptado: 16-VI-2008 